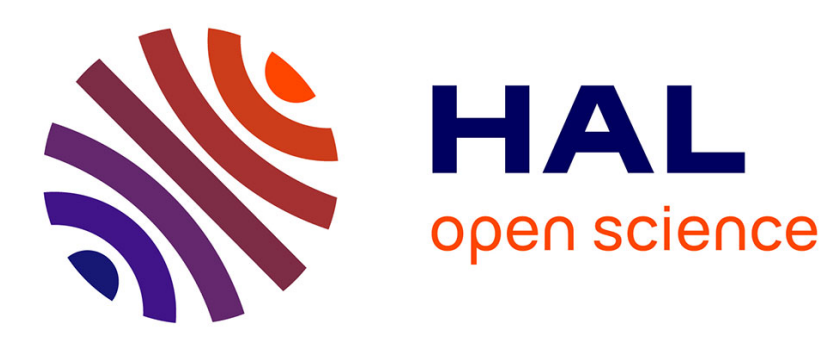

\title{
A comparison of interfacial behaviours of pea (Pisum sativum L.) legumin and vicilin at airwater interface
}

\author{
C. Dagorn-Scaviner, J. Lefebvre
}

\section{To cite this version:}

C. Dagorn-Scaviner, J. Lefebvre. A comparison of interfacial behaviours of pea (Pisum sativum L.) legumin and vicilin at airwater interface. Nahrung., 1986, 30, pp.vol. 30 no. 3. hal-02724050

\section{HAL Id: hal-02724050 \\ https://hal.inrae.fr/hal-02724050}

Submitted on 2 Jun 2020

HAL is a multi-disciplinary open access archive for the deposit and dissemination of scientific research documents, whether they are published or not. The documents may come from teaching and research institutions in France or abroad, or from public or private research centers.
L'archive ouverte pluridisciplinaire HAL, est destinée au dépôt et à la diffusion de documents scientifiques de niveau recherche, publiés ou non, émanant des établissements d'enseignement et de recherche français ou étrangers, des laboratoires publics ou privés. 
Ministere de l'Agriculture, Institut National de la Recherche Agronomique, Laboratoire de Biochemie et Technologie des Protéines, Nantes-Cédex, France

\title{
A comparison of interfacial behaviours of pea (Pisum sativum L.) legumin and vicilin at air/water interface
}

\author{
C. Dagorn-Scaviner, J. Gueguen and J. Lefebvre
}

The interfacial behaviours of the two main pea globulins (legumin and vicilin) at water/air interfaces were studied in order to improve the general knowledge concerning the physicochemical basis of the foaming and emulsifying properties of these proteins. The surface tension $(\gamma)$ was monitored by the WILHELMY plate technique till it reaches a constant value. The final concentration $c$ of the proteins injected in the subphase was comprised between $0.3 \cdot 10^{-6}$ and $80 \cdot 10^{-6} \mathrm{~g} / \mathrm{ml}$. The adsorption kinetics $\gamma=f(t)$ were analyzed using different mathematical relations given in the literature. Different phases can be distinguished, corresponding to the diffusion, penetration and rearrangement of protein molecules at the interface, each phase being characterized by a rate constant and an energy barrier.

The rate constants were generally higher in the case of vicilin; in consequence the equilibrium surface pressure $\pi$ were reached more quickly. The isotherms $\pi_{e}=f(\log c)$ showed that the concentration needed to reach the plateau value of $\pi_{e}$ were respectively about $11.7 \cdot 10^{-6} \mathrm{~g} / \mathrm{ml}$ and $18.5 \cdot 10^{-6} \mathrm{~g} / \mathrm{ml}$ for vicilin and legumin at air/water interface. The plateau value of $\pi_{e}$ was about the same for both proteins at air/water interface (24.5 $\mathrm{mN} / \mathrm{m}$ ). For lower concentrations, vicilin gave higher values for $\pi_{e}$. The areas per molecule in the adsorbed monolayer were about the same for vicilin $\left(1.05 \mathrm{~nm}^{2}\right)$ and legumin $\left(1.04 \mathrm{~nm}^{2}\right)$ at air/water interface.

By studying the surface properties of vicilin/legumin mixtures it was observed that $\pi_{e}$ increased with increasing relative concentration of vicilin and that inhibiting interactions occured between the two globulins, legumin adsorption being more disturbed by vicilin than the opposite.

According to these results, the differences between legumin and vicilin can be related to their molecular characteristics. Pea globulins and especially vicilin appeared to be efficient proteins as surface active agents.

\section{Introduction}

According to the studies on their functional properties, pea protein isolates seem to provide high emulsifying and foaming properties [16, 19]. Because these properties are closely related to the surface activity of the proteins, the interfacial behaviours of the two main pea globulins, vicilin and legumin, were compared at air/water interface. In order to simulate the use of isolates as surface active agents, these two globulins mixed in various proportions were also studied.

The kinetics and isotherms of the protein adsorption, monitored by the WILHELMY plate method, were analysed in terms of conformation and structure, as previously done by TORNBERG $[17,18]$ and GRAHAM et al. [9-11] on model proteins. These last authors specially showed that the hydrophobic disordered $\beta$-casein molecules were more surface active than the globular bovine serum albumin (BSA) and lysozyme molecules. Because of its flexibility, $\beta$-casein adopted at equilibrium a close-packed condensed state whereas lysozyme molecules prevented from complete unfolding by disulfide linkages were assembled in the interfacial layers as ellipsoidal organizations. Because pea globulins have quite different tertiary and 
quaternary structures the parameters of adsorption kinetics and isotherms were compared for both proteins to those of the previous model proteins. It was expected that the physicochemical phenomena of interfacial adsorption should be different for legumin and vicilin, according to the fact that legumin has a higher molecular weight and a more complex and rigid quaternary structure composed of six pairs of acidic and basic subunits by disulfide bridges $[2,5-7]$.

\section{Material and methods}

\section{Materials}

Pea globulins were prepared from a crude pea protein extract by a two steps chromatographic procedure. Vicilin and legumin were separated by ion exchange chromatography on DEAE Sepharose and then purified by gel filtration on ultrogel ACA 34 as described elsewhere [12]. The chromatographic procedure as well as the buffer used in the study led to solutions of the globulins in their native state [12].

Bovine serum albumin (BSA) was an essentially fatty-acid-free sample from Sigma chemical company (reference A-7511).

\section{Methods}

The surface tension $\gamma$ was measured at $20^{\circ} \mathrm{C}$ by the WILHELMY plate technique using a Prolabo tensiometer and the $\gamma-t$ curves $(t=$ time) were recorded to a constant value of $\gamma$.

The thermostated trough (approximate diameter $68 \mathrm{~mm}$ and $37 \mathrm{~mm}$ high) was filled with $25 \mathrm{ml}$ of sodium phosphate buffer $\left(\mathrm{NaH}_{2} \mathrm{PO}_{4}, 0.1 \mathrm{M}, \mathrm{pH}\right)$ ). 30 to $250 \mu 1$ of protein solutions $(1 \mathrm{mg} / \mathrm{ml}$ to $10 \mathrm{mg} / \mathrm{ml})$ were injected, leading to a final concentration comprised between $0.3 \cdot 10^{-6}$ and $80 \cdot 10^{-6} \mathrm{~g} / \mathrm{ml}$. The homogeneization of the protein sample in the lower phase was improved by a weak and short $(30 \mathrm{~s})$ magnetic stirring.

In order to determine the various parameters which control the successive rate steps of the interfacial pressure $(\pi)$ kinetics, the commonly used plots $[9,17,18,20] \pi=f\left(t^{1 / 2}\right), \log \frac{\mathrm{d} \pi}{\mathrm{d} t}=f(\pi), \log \left(1-\frac{\pi}{\pi_{e}}\right)=f(t)$ were established on a HP 9825 computer. The interfacial pressure $\pi$ plotted versus $t^{1 / 2}$ showed a linear region, giving the limit of the diffusion controlled phase [17].

The $\log \frac{\mathrm{d} \pi}{\mathrm{d} t}$ versus $\pi$ curve was divided by regression analysis into successive linear parts, each of them corresponding to a kinetic step. The limits of these steps were optimized and adjusted in order to be in agreement with those found by using the representation $\log \left(1-\frac{\pi}{\pi_{e}}\right)$ versus $t$ ( $\pi_{e}$ equilibrium interfacialpressure [9]. According to the equation given by TORNBERG [17] $\log \frac{\mathrm{d} \pi}{\mathrm{d} t}=k^{\prime}-\pi \Delta A / k T(k=$ BolTZMANN's constant, $T=$ temperature), $\Delta A$ is the mean surface area that one active segment of the protein needs to clear out in order to be adsorbed at the interface. $\Delta A$ is a measure of the energy barrier to adsorption. For each kinetic step $\Delta A$ can be calculated from the slope of the corresponding linear section of the $\log \frac{\mathrm{d} \pi}{\mathrm{d} t}$ versus $\pi$ plot.

The rate $k=1 / T$ ( $T=$ relaxation time) of each process can be obtained from the first order equation $\log \left(1-\frac{\pi}{\pi_{e}}\right)=-t / T[9] ;$ it is given by the slope of the corresponding linear segment of the graph $\log \left(1-\frac{\pi}{\pi_{e}}\right)$ versus $t$. 


\section{Results and discussion}

Kinetics of adsorption of legumin and vicilin at air/water interface

When the adsorption kinetics of legumin and vicilin for similar concentrations were compared, vicilin appeared generally to be adsorbed faster and reached its equilibrium surface $\left(\pi_{e}\right)$ sooner (Fig. 1).

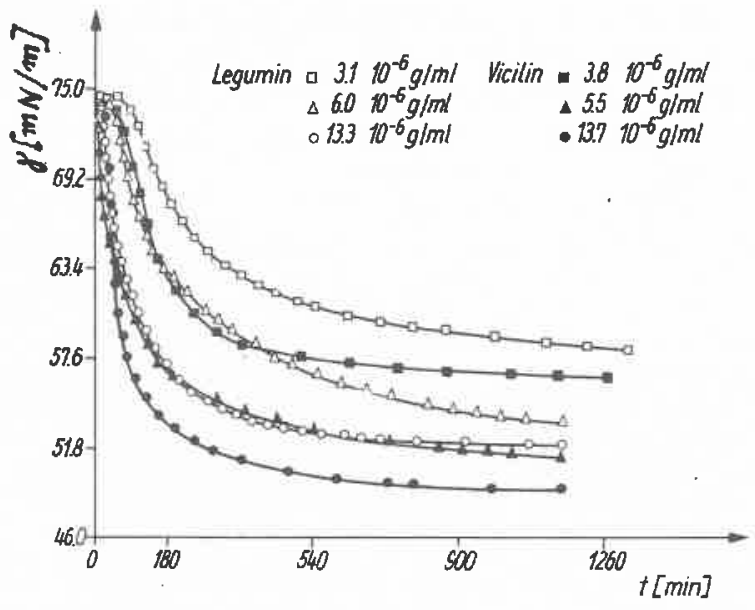

Fig. 1.

Adsorption kinetics of legumin and vicilin for various concentrations.

For both proteins, the kinetics were composed of two steps at low concentrations. Three phases referred to for commodity in the paper, as (1), (2) and (3), appeared for protein concentrations above $1.3 \cdot 10^{-6} \mathrm{~g} / \mathrm{ml}$ and $3.8 \cdot 10^{-6} \mathrm{~g} / \mathrm{ml}$ in case of vicilin and legumin respectively. A fourth step (4) was observed for legumin at concentrations higher than $33.2 \cdot 10^{-6} \mathrm{~g} / \mathrm{ml}$ but not for vicilin.

According to the studies of GRAHAM [8] the different steps were ruled successively by the diffusion of the molecules to the interface, by their penetration into the surface film and last by molecular rearrangements within the adsorbed layer. In fact a preliminary step, referred to as zero in this paper, was generally observed before the linear relation between $\pi$ and $t^{1 / 2}$, which is commonly taken in the literature as the criterion for a diffusion controlled kinetic process $[8,17,20]$, was reached. The variations of the surface pressure $(\pi)$ during this phase 0 could not be neglected and were comprised between 0.4 and $4.1 \mathrm{mN} / \mathrm{m}$ for legumin, 0.5 and $7.2 \mathrm{mN} / \mathrm{m}$ for vicilin, over the range of concentration studied. This step was generally short and represented only about $1 \%$ to $4 \%$ of the total time of the kinetics. This initial period was also observed by other authors. TORNBERG [17] who used the drop volume method ascribed it to "the enlargement of the surface of the drop accomplished by the surface tension decay of the first arrived molecules". BLANK et al. [1] concluded that "the observed dependence of the surface pressure data on $t^{1 / 2}$ did not follow directly from diffusion limited adsorption and may be entirely fortuitous".

According to our results, this phenomenon does not seem to be related with the measurement method but could be attributed, first to the time necessary to obtain a continuous gradient of protein concentration between the injection area and the interface as described by WARD et al. [20] and secondly to specific characteristics of the protein sample. As an 
hypothesis, small molecules included in the samples as traces could be early adsorbed at the interface. In fact, legumin and vicilin samples contained respectively $0.05 \%$ and $0.16 \%$ of lipids expressed as total fatty acids. But these lipids are very tightly attached to the proteins and, besides, the preliminary step is also observed in case of the fatty-acid free BSA used in this study. A more likely explanation is presented below in connection with the discussion about step (1). When comparing the different periods of the adsorption to each other for both proteins, the step (2) was generally rather short but seemed to be the most efficient period to increase the surface pressure. Its relative contribution $\left(\Delta \pi / \pi_{e}\right)$ was comprised between $25 \%$ and $50 \%$ whereas in most cases, it did not span more than $15 \%$ of the total time of the kinetics. At the opposite, period (3) was always the longest but induced only little modification of the surface pressure.

The period (1) became shorter as the protein concentration increased. The corresponding time interval was comprised between $135 \mathrm{~min}$ and $18 \mathrm{~min}$ for vicilin, and $120 \mathrm{~min}$ and $8 \mathrm{~min}$ for legumin respectively at the lower and higher concentrations.

On the other hand, the influence of the bulk protein concentration on $\Delta A 1$ corresponding to energy barrier relative to the step 1 was not very important. $\triangle A 1$ was comprised between $0.4 \mathrm{~nm}^{2}$ and $0.5 \mathrm{~nm}^{2}$ for both globulins. These low values indicated a weak energy barrier at the interface and an easy adsorption of the molecules. The same characteristics were also observed on model proteins. We have found $\triangle A 1=0.4 \mathrm{~nm}^{2}$ for BSA; TORNBERG [17] obtained about the same value for BSA and lactoglobulin.

The existence of an energy barrier $\Delta A 1$, definite however small it is, shows that this step (1) is not only controlled by diffusion. According to BLANK et al. [1] electrical factors, related to the charge of the macromolecules and the orientation of the water dipole at the interface, also influence the adsorption rate. Such factors, and specially the organisation of water molecules on the interface which is "melted" after a small amount of solute has entered the surface [13] might also explain at least partly the existence of the preliminary period (step 0) preceeding step (1). $\triangle A 2$ which corresponds to the step.(2) of the kinetics, was generally higher than $\Delta A 1$ (from $0.30 \mathrm{~nm}^{2}$ to $3.68 \mathrm{~nm}^{2}$ for legumin and from $0.4 \mathrm{~nm}^{2}$ to $1.75 \mathrm{~nm}^{2}$ for vicilin) and was modified to a large extent by the protein concentration (Fig. 2). The $\triangle A 2$ variation profiles were similar for both globulins, but shifted for vicilin to lower concentrations (Fig. 2). $\Delta A 2$ decreased first, then increased to a maximum and slightly decreased again to a constant value. The intermediate maxima, around $1.45 \mathrm{~nm}^{2}$ and $0.80 \mathrm{~nm}^{2}$ for vicilin

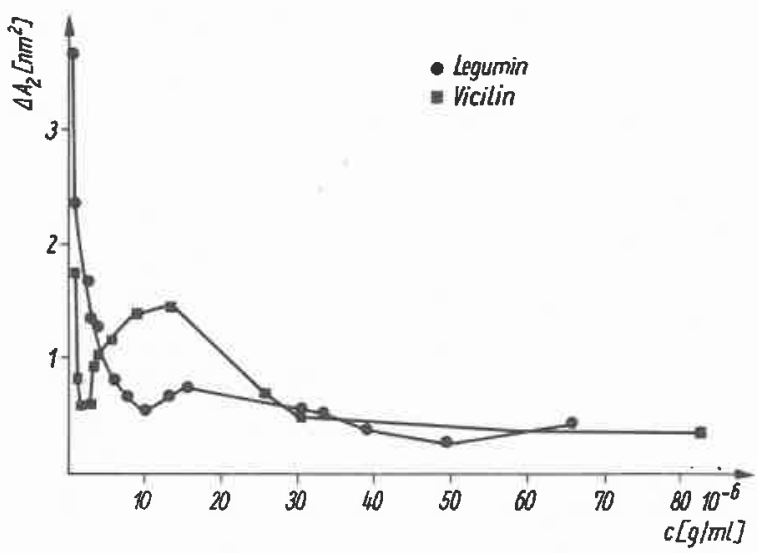

Fig. 2.

Variation of $\triangle \mathrm{A} 2$ with the concentration. 
and legumin respectively, were obtained for $13.7 \cdot 10^{-6} \mathrm{~g} / \mathrm{ml}$ and $16 \cdot 10^{-6} \mathrm{~g} / \mathrm{ml}$. The $\triangle A 2$ plateau values were reached for concentrations above $35 \cdot 10^{-6} \mathrm{~g} / \mathrm{ml}$ and did not differ much for the two proteins $\left(0.25 \mathrm{~nm}^{2}\right.$ for vicilin, $0.40 \mathrm{~nm}^{2}$ for legumin).

These variations of $\triangle A 2$ are not easy to explain. The increase of interfacial protein concentration could induce modifications of the conformation of the adsorbed proteins which lead to the non-monotonous variation of the energy barrier observed.

According to the $\Delta A$ values we obtained with BSA, and those calculated on the basis of the results of GrAHAM et al. [9] for $\beta$-casein and lysozyme, it seems that the adsorption behaviour of vicilin during the penetration phase (step 2) was closer to that of BSA as compared to legumin which was intermediate between BSA and lysozyme. At concentration about $0.6 \cdot 10^{-6} \mathrm{~g} / \mathrm{ml}, \triangle A 2$ was around $1.30 \mathrm{~nm}^{2}, 1.73 \mathrm{~nm}^{2}$ and $2.35 \mathrm{~nm}^{2}$ respectively for BSA, vicilin and legumin whereas it reached $3.38 \mathrm{~nm}^{2}$ for lysozyme and was only $1.15 \mathrm{~nm}^{2}$ for $\beta$-casein.

At low concentrations, $\triangle A 2$ decreases steeply with concentration for all proteins, and this behaviour can be thought to reflect just the increasing crowding of the interface by protein molecules, without any interference from some protein conformational changes inside the interfacial layer, we have already alluded, or some interaction process in the solution, which could happen at higher concentrations. Thus, $\triangle A 2$ values at low concentrations can be related directly to the conformational characteristics of the proteins.

The relatively low value of $\Delta A 2$ at low concentrations for vicilin as compared to lysozyme and its similarity with BSA mean that the conformation of this globulin is not so rigid as that of lysozyme. However, one could have expected it to be still lower and closer to that of $\beta$-casein, this pea globulin being devoided of disulfide bridges. The experimental results might be ascribed to a quite compact structure of vicilin as it was shown for the $7 \mathrm{~S}$ soybean globulin [4]. The high value $\triangle A 2$ for legumin, intermediary between that of BSA and lysozyme, results probably from the rigidity of this protein due to its complex quaternary structure bound by disulfide bridges. $\triangle A 3$ varied also with protein concentration, in an even more complicated fashion than $\triangle A 2$. For both pea globulins, it remained generally in the range $2.00-3.00 \mathrm{~nm}^{2}$. A maximum was observed at $8.8 \cdot 10^{-6} \mathrm{~g} / \mathrm{ml}\left(A 3=4.40 \mathrm{~nm}^{2}\right)$ for vicilin and at $13.3 \cdot 10^{-6} \mathrm{~g} / \mathrm{ml}\left(\triangle A 3=2.70 \mathrm{~nm}^{2}\right)$ for legumin. $\triangle A 3$ values were systematically higher for vicilin than for legumin. If step (3) is considered as corresponding to a phase of rearrangements of the adsorbed protein molecules within the interface layer, then it could be infered from this fact either that rearrangement processes are more extensive in the case of vicilin, or that the conformation of the protein in the adsorbed layer at the end of step 2 is less rigid in the case of legumin.

By plotting the relaxation times $T 1, T 2$ and $T 3$ corresponding to each step, versus the protein concentration in the solution, the resulting curves had similar profiles for vicilin, legumin and BSA, except for legumin data being shifted to higher concentrations.

$T 1$ did not vary much with concentration and remained in the range $1-3 \mathrm{~h}$ for the three proteins. It appeared at low concentrations that the larger the molecular weight the higher the relaxation time was, which is consistent with the step (1) being partly controlled by the diffusion rate. On the other hand $T 2$ (Fig. 3) was more affected by the concentration. It decreased first for low concentrations and reached a constant value for concentrations above $2.5 \cdot 10^{-6} \mathrm{~g} / \mathrm{ml}, 4 \cdot 10^{-6} \mathrm{~g} / \mathrm{ml}$ and $6 \cdot 10^{-6} \mathrm{~g} / \mathrm{ml}$ respectively for BSA, vicilin and legumin. For all three proteins the plateau value of $T 2$ was around $2 \mathrm{~h} . T 2$ was always lower for vicilin than for legumin. According to the interpretation of GRAHAM et al. [9] and by comparison with their results on the randomly coiled protein $\beta$-casein, replotted on Fig. 3 , 


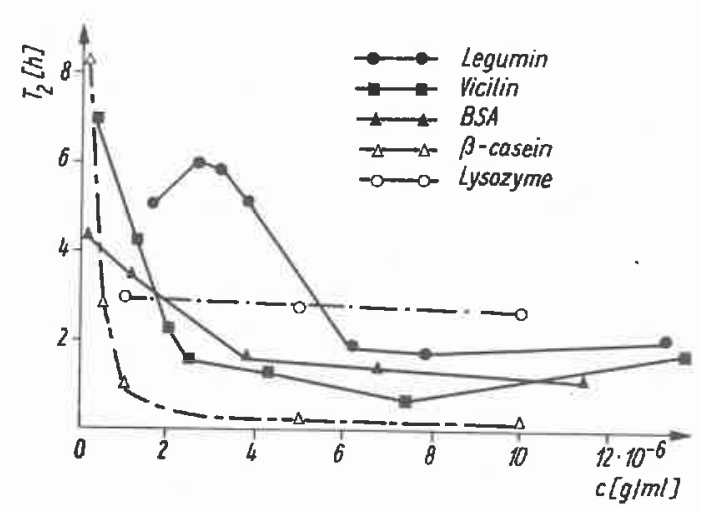

Fig. 3.

Variation of $T_{2}$ with protein concentrations: comparison of the results obtained for legumin, vicilin, BSA with GrahaM's data [8] on $\beta$ casein and lysozyme.

this fact can be ascribed to a greater flexibility of vicilin. This result is indeed in agreement with the absence of disulfide bonds in vicilin and the previous results on $\triangle A 2 . T 3$ also varied in a large extent all over the range of concentrations studied. The lower data were obtained for BSA $(2$ to $5 \mathrm{~h}$ ) whereas they were comprised between 3 and $8 \mathrm{~h}$ for pea globulins. It means that vicilin and legumin films were less compressible than the BSA one [9].

In summary, the differences between vicilin and legumin adsorption kinetics are connected to their different structure and conformation. Vicilin, because of its lower molecular size and its higher flexibility reaches the interface faster, is adsorbed more easily and leads to more compressible film.

\section{Adsorption isotherms}

The adsorption isotherms were composed for legumin, vicilin as well as for BSA by a first part in which the equilibrium interfacial pressure $\left(\pi_{e}\right)$ linearly increased with $\log c$, followed for higher protein concentrations by a second part corresponding to a plateau value of $\pi_{e}$ (Fig. 4). This plateau value of $\pi_{e}$ was very close for both pea globulins $(24.5 \mathrm{mN} / \mathrm{m})$ and lower for BSA (19 mN/m). GRAHAM et al. [10] found $24 \mathrm{mN} / \mathrm{m}$ for $\beta$-casein and $17 \mathrm{mN} / \mathrm{m}$ for $\mathrm{BSA}$; but their samples were acetylated and the experimental conditions were slightly different ( $\mathrm{pH} 7$ instead of 8).

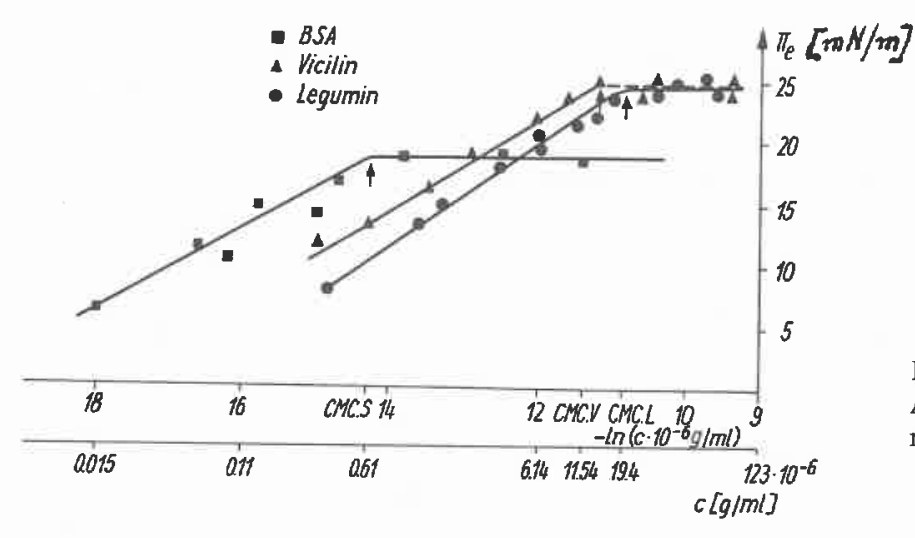

\section{Fig. 4.}

Adsorption isotherms for legumin, vicilin and BSA. 
The point for which the plateau value was reached corresponded for the three proteins to different concentrations: $0.6 \cdot 10^{-6} \mathrm{~g} / \mathrm{ml}, 11.7 \cdot 10^{-6} \mathrm{~g} / \mathrm{ml}$ and $18.5 \cdot 10^{-6} \mathrm{~g} / \mathrm{ml}$ for BSA, vicilin and legumin respectively. This singular point corresponds in the case of low molecular weight surfactants to a critical micelle concentration, was also observed for caseinate at $10 \cdot 10^{-6} \mathrm{~g} / \mathrm{ml}$ by TORNBERG [17] and was attributed by this author according to the data of SCHMIDT et al. [15] to the formation of casein micelles. From Fig. 4, BSA appears to be a more efficient protein as compared to pea globulins, in increasing the surface pressure when the concentrations were lower than $8 \cdot 10^{-6} \mathrm{~g} / \mathrm{ml}$. But at higher concentrations, the surface activity of pea globulins was higher, slightly better for vicilin.

Before the plateau region, an adsorption isotherm can be described by GIBB's equation

$\mathrm{d} \pi / \mathrm{d} \ln c=k T / A \quad[14]$

where $A$ is the interface area for molecule in the adsorbed monolayer, $k$ BoltzMANN's constant, and $T$ the absolute temperature. The values of $A$ for each of the proteins studied, calculated from the slope of the adsorption isotherm, were $1.04 \mathrm{~nm}^{2}, 1.05 \mathrm{~nm}^{2}, 1.40 \mathrm{~nm}^{2}$ respectively for legumin, vicilin and BSA. They are quite close to the data of GraHAM [9] for BSA $\left(1.16 \mathrm{~nm}^{2}\right)$ and lysozyme $\left(1.40 \mathrm{~nm}^{2}\right)$ but very different from the $\beta$ casein value $\left(0.49 \mathrm{~nm}^{2}\right)$. The higher value of $A$ compared to $\beta$-casein which has a very flexible, randomly coiled structure, results from the more rigid conformations of pea globulins which induced a lesser compressibility of the film. The tertiary structures of vicilin and legumin appear to be compact structures [4] which remain partly stabilised, even after adsorption, mainly by hydrophobic interactions and, in the case of legumin, also by disulfide bonds.

\section{Surface properties of globulins mixed solutions for various legumin/vicilin ratio}

The surface properties of mixed solutions of the two pea globulins was also studied as a model of protein isolates. Because of the lesser efficiency as a surface active component of legumin as compared to vicilin, specially in the low protein concentration region, it was expected that the ratio legumin/vicilin (L/V) should modify the adsorption behaviours of the mixture, at least the equilibrium surface pressure. The influence of the ratio was studied in the range $0.2-5$ in agreement with the genetic variations observed in pea seeds $[3,5,6]$. The kinetics were carried out at two bulk concentrations: $2.5 \cdot 10^{-6} \mathrm{~g} / \mathrm{ml}$ and $30 \cdot 10^{-6} \mathrm{~g} / \mathrm{ml}$. The lower value is situated on the ascending part of the isotherms whereas the higher was choosen in order that the concentration of one of the protein at least was on the plateau value of $\pi_{e}$.

The resulting $\pi_{e}$ data of the mixture were compared to those obtained from the isotherm plots for each globulin taken alone at the same concentration as it was in the mixed solution. For example if $L / V=2$ for a bulk concentration of $2.5 \cdot 10^{-6} \mathrm{~g} / \mathrm{ml}$, the contribution of each protein considered separatively should be equivalent to the $\pi_{e}$ obtained at $0.83 \cdot 10^{-6} \mathrm{~g} / \mathrm{ml}$ and $1.66 \cdot 10^{-6} \mathrm{~g} / \mathrm{ml}$ respectively for vicilin and legumin. From Fig. 5 , it appears in fact that for both bulk concentrations studied, $\pi_{e}$ regularly decrease' with increasing $L / V$ ratios.

At $2.5 \cdot 10^{-6} \mathrm{~g} / \mathrm{ml}$ and for $V / L>1$ (Fig. $5 \mathrm{a}$ ), $\pi_{e}$ for the mixtures were comprised between the values corresponding to vicilin alone at its effective concentration in the system and those corresponding to vicilin at $2.5 \cdot 10^{-6} \mathrm{~g} / \mathrm{ml}$. The efficiency of the mixture was thus 

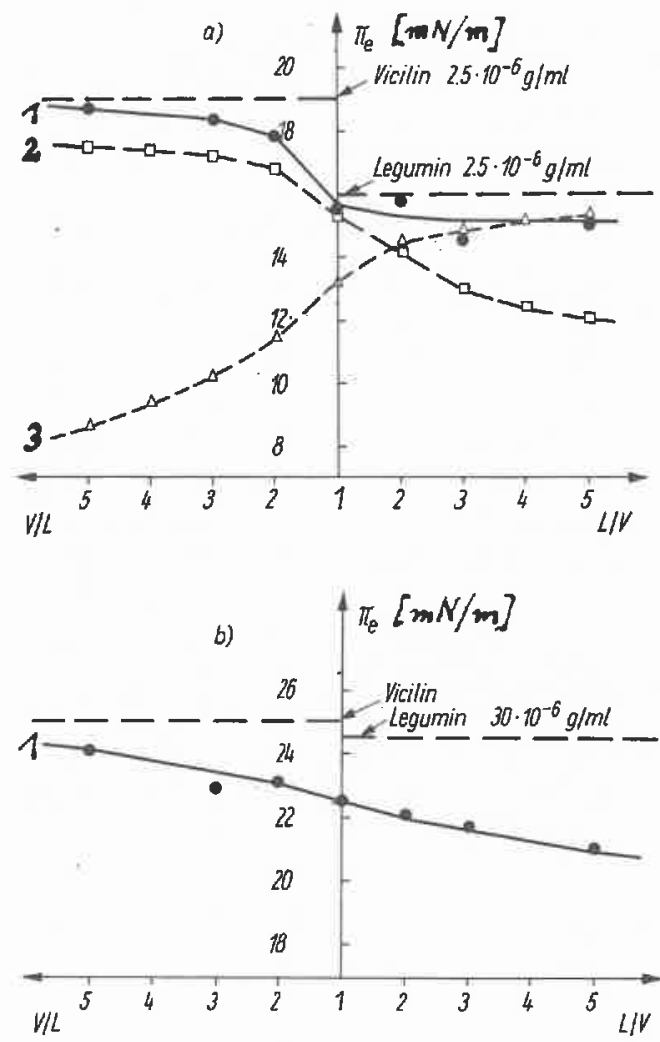

Fig. 5.

a) Variation of the equilibrium surface pressure $\left(\pi_{e}\right)$ with the Legumin/vicilin ratio at a bulk $1=$ vicilin/legumin mixture

$2=$ vicilin contribution

$3=$ legumin contribution

protein concentration of $2.5 \cdot 10^{-6} \mathrm{~g} / \mathrm{ml}$.

b) Variation of the equilibrium surface pressure $\left(\pi_{e}\right)$ with the Legumin/vicilin ratio at a bulk protein concentration of $30 \cdot 10^{-6} \mathrm{~g} / \mathrm{ml}$.

lower than that of a vicilin solution of equivalent concentration. Nevetheless, the addition of legumin improved the equilibrium surface pressure. When $L / V>1$ a quite similar phenomenon was observed. The mixture was less active as compared to legumin alone at $2.5 \cdot 10^{-6} \mathrm{~g} / \mathrm{ml}$ and moreover the contribution of the vicilin added in the mixture in increasing $\pi_{e}$ was lower than that previously observed for legumin when $V / L>1$. It seems that for $L / V>3$ vicilin could not be adsorbed in the legumin interface layer whereas the opposite was possible when vicilin was the major protein in the mixture. The structure of the film should be different for the two globulins. According to our previous results, the vicilin film being more compressible allowed the adsorption of legumin.

At $30 \cdot 10^{-6} \mathrm{~g} / \mathrm{ml}$ (Fig. $5 \mathrm{~b}$ ) for every ratio, the concentration of the major globulin is situated on its isotherm plateau when taken alone $(25 \mathrm{mN} / \mathrm{m}$ for $V / L>1$ and $24.5 \mathrm{mN} / \mathrm{m}$ for $L / V>1$ ). In fact, the equilibrium surface pressure were in all cases lower and were regularly decreasing with increasing legumin content. For example, for a $L / V$ ratio of $5, \pi_{e}$ was only $21 \mathrm{mN} / \mathrm{m}$ instead of $24.5 \mathrm{mN} / \mathrm{m}$ for legumin alone at an equivalent concentration $\left(25 \cdot 10^{-6} \mathrm{~g} / \mathrm{ml}\right)$. According to these results, some inhibiting interactions take place between the two globulins. At $2.5 \cdot 10^{-6} \mathrm{~g} / \mathrm{ml}$ this effect coult not be observed; at low concentration, the addition of a protein even in small amount in the mixture led to an increase of $\pi_{e}$ due to the increase in the total protein concentration. At $30 \cdot 10^{-6} \mathrm{~g} / \mathrm{ml}$ small quantity of legumin added to vicilin did not modify however appreciably its surface activity; at the opposite a small amount of vicilin in legumin sample seemed to affect very much 
its efficiency. This confirms the different structures of vicilin and legumin films. Moreover the protein layers being heterogeneous when the two globulins adsorb together, they adopt a molecular organization which is different as compared to that resulting from the adsorption of the pure proteins. The minor protein seems to disturb the molecular rearrangement processes in the interfacial layer the more they are complex. We have noticed that $\triangle A 3$ values were low in the case of pure legumin; they are substantially higher for legumin/vicilin mixtures at high $L / V$ ratios; so, the presence of vicilin molecules in the legumin film inhibits probably some denaturation process which involves the dissociation of the legumin subunits and their reaggregation. Such phenomena could explain the lesser efficiency of legumin in the presence of vicilin. At the opposite, vicilin, less sensitive to denaturation (J. GUEGUEN, unpublished results) and for which rearrangements are not so important, was less disturbed by legumin adsorption. By consequence its surface activity was not affected to the same extent. In summary, it seems from a practical point of view more efficient in order to increase the surface pressure to use a vicilin-rich mixture in which the $V / L$ ratio is as high as possible.

\title{
Conclusion
}

According to this study, the kinetic parameters of adsorption at air/water interface were quite similar for vicilin and legumin, except for the relaxation times which were shortened in the case of vicilin. Because of its lower molecular weight and its probably more flexible tertiary structure, the rates of the successive adsorption steps were higher for vicilin. As compared to BSA, the adsorption isotherms of pea globulins seemed to be shifted to the higher concentrations, specially in the case of legumin. The efficiency of BSA was better at low concentrations, but for higher concentrations the $\pi_{e}$ values at the isotherm plateau were higher for pea globulins, vicilin being more efficient than legumin.

As for the vicilin-legumin mixtures, the better surface behaviours were obtained when vicilin was the major protein. Legumin efficiency was very affected by addition of vicilin. And in order to improve the surface properties of isolates, it would probably be better to extract proteins from vicilin rich pea varieties.

\section{Acknowledgements}

Thanks are due to Oleagri Recherche Developpement for their financial support

\author{
Zusammenfassung \\ C. DAGORN-SCAviner, J. GuEguen und J. LeFEBVRE: Ein Vergleich des Grenzflächenverhaltens von Legumin \\ und Vicilin der Erbse (Pisum sativum L.) an Luft/Wasser-Grenzflächen
}

Es würde das Grenzflächenverhalten der zwei Hauptglobuline der Erbse (Legumin und Vicilin) an Wasser/ Luft-Grenżlächen untersucht, um die allgemeinen. Kenñtnišse über physikalisch-chemische Grundlagen der Verschäumungs- und Emulgier-Eigenschaften dieser Proteine zu erweitern. Die Oberflächenspannung $(\gamma)$ wurde durch die WILHELMY-Platten-Technik bis zum Erreichen konstanter Werte gemessen. Die in die Subphase gegebene Endkonzentration $c$ der Proteine lag zwischen $0,3 \cdot 10^{-6}$ und $80 \cdot 10^{-6} \mathrm{~g} / \mathrm{ml}$. Die Adsorptionskinetik $\gamma=f(t)$ wurde durch verschiedene mathematische Gleichungen aus der Literatur analysient. 
Die verschiedenen Phasen können entsprechend der Diffusion, der Penetration und der Reorganisierung der Proteinmoleküle an der Grenzfläche unterschieden werden, wobei jede Phase durch eine Geschwindigkeitskonstante und eine Energiebarriere charakterisiert ist.

Die Geschwindigkeitskonstanten waren beim Vicilin im allgemeinen höher, und der GleichgewichtsOberflächendruck $\pi$ wurde entsprechend schneller erreicht. Die Isotherme $\pi_{e}=f(\log c)$ zeigte, daß die zur Erreichung der Plateau-Werte von $\pi_{e}$ erforderlichen Konzentrationen etwa $11,7 \cdot 10^{-6} \mathrm{~g} / \mathrm{ml}$ für Vicilin und $18,5 \cdot 10^{-6} \mathrm{~g} / \mathrm{ml}$ für Legumin an Luft/Wasser-Grenzflächen betrugen. Der Plateau-Wert für $\pi_{e}$ war für beide Proteine an Luft/Wasser-Grenzflächen etwa gleich $(24,5 \mathrm{mN} / \mathrm{m})$. Bei niedrigen Konzentrationen ergab Vicilin höhere Werte für $\pi_{e}$. Die Flächen pro Molekül in der adsorbierten Monoschicht waren für Vicilin $\left(1,05 \mathrm{~nm}^{2}\right)$ und Legumin $\left(1,04 \mathrm{~nm}^{2}\right)$ an Luft/Wasser-Grenzflächen etwa gleich.

Beim Studium der Oberflächeneigenschaften von Vicilin/Legumin-Mischungen wurde beobachtet, daß $\pi_{e}$ mit steigender relativer Konzentration an Vicilin zunahm und daß hemmende Wechselwirkungen zwischen den beiden Globulinen auftraten, wobei die Legumin-Adsorption durch Vicilin stärker gestört wurde als umgekehrt.

Nach diesen Resultaten können die Unterschiede zwischen Legumin und Vicilin auf ihre molekularen Eigenschaften zurückgeführt werden. Erbsen-Globuline und insbesondere Vicilin erwiesen sich als wirksame Proteine für oberflächenaktive Agentien.

\section{Резгоме}

К. ДАГорН-СКАвинеР, Й. ГьЕТЬЕН и Й. ЛЕФЕвР: Сравнение поведения на границе раздела фаз леГУмина и вицилина гороха (Pisum sativum L.) на границе раздела фаз воздух/вода

Исследовалось поведение на границе раздела фаз двух основных глобулинов гороха (легумин и вицилин) на границе раздела фаз воздух-вода, чтобы расширить общие представления о физико-химкческих основах вспенивающих и эмульгирующих свойств этих белков. Поверхностное натяжение $(\gamma)$ измерилось с помощью техники пластинок по Вилхелмы до достижения постоянных величин. Внесенная в субфазу конечная концентрация „, с" белков расположена между $0,3 \cdot 10^{-6}$ и $80 \cdot 10^{-6} г / \mathrm{Mл}$. Адсорбционная кинетика $\gamma=f(t)$ анализировалась путем различных математических уравнений взятых из литературы. Различные фазы можно отличить на основе диффузии, пенетрации и реориентации белковых молекул на границе раздела фаз, при этом каждая фаза характеризуется постоянной скоростью и энергетическим барьером.

Постоянные скорости были как правило выше у вицилина и равновесие давления на поверхность $\pi$ достигалось соответственно быстрее. Изотерма $\pi_{e}=f(\log c)$ показала, что необходимые для достижения данных плато $\pi_{e}$ концентрации составляют примерно $11,7 \cdot 10^{-6} \mathrm{\Gamma} /$ мл для вицилина и 18,5 $\times 10^{-6}$ г/мл для легумина на границах раздела фаз воздух/вода. Значение плато для $\pi_{e}$ для обоих белков на пограничных слоях воздух/вода было примерно одинаковым 24,5 мН/м. При низких концентрациях вицилин показал более высокие значения для $\pi_{e}$. Поверхности на 1 молекулу в адсорбированном монослое были для вицилина $\left(1,05 \mathrm{Hм}^{2}\right)$ и легумина $\left(1,04 \mathrm{Hм}^{2}\right)$ на пограничных слоях воздух/вода примерно одинаковы.

При изучении поверхностных свойств смесей вицилина/легумина наблюдалось, что $\pi_{e}$ с увеличением относительной концентрации вицилина повышается и что возникали ингибирующие взаимодействия между обоими глобулинами, при этом адсорбция легумина больше страдала от вицилина чем наоборот.

Исходя из этих результатов различия между легумином и вицилином связаны с их молекулярными свойствами. Глобулины гороха и особенно вицилин являются действенными белками для поверхностноактивных реактивов.

\section{References}

[1] Blank, M., B. B. LeE and J. S. Britten, J. Colloid Interface Sci. 50, 215 (1975).

[2] CASEY, R., Biochem. J. 177, 509 (1975).

[3] Casey, R., J. E. Sharman, D. J. Wright, J. R. Bacon and P. Guldager, Qual. Plant. Plant Foods Hum. Nutr. 31, 333 (1982). 
[4] Fukushima, D., Cereal Chem. 45, 203 (1968).

[5] Gatehouse, J. A., R. R. D. Croy, R. Mc Intosh, C. Paul and D. Boulter, in D. A. Bond (editor), Vicia faba: Feeding value. Processing and viruses, p. 173 (1980).

[6] Gatehouse, J. A., R. R. D. Croy and D. Boulter, Biochem. J. 185, 497 (1980).

[7] Gatehouse, J. A., R. R. D. Croy, H. Morton, M. Tyler and D. Boulter, Eur. J. Biochem. 118, 627 (1981).

[8] Graham, D. E., Ph. D. Thesis, CNAA, London 1976.

[9] Graham, D. E., and M. C. Phillips, J. Colloid Interface Sci. 70, 403 (1979).

[10] Gralfam, D. E., and M. C. Phillips, J. Colloid Interface Sci. 70, 415 (1979).

[11] Graham, D. E., and M. C. Phillips, J. Colloid Interface Sci. 70, 427 (1979).

[12] Gueguen, J., A. T. Vu and F. Schaeffer, J. Sci. Fd. Agric. 35, 1024 (1984)

[13] Hansen, R. S., J. Colloid Sci. 16, 549 (1961).

[14] Mac Ritchie, F., Adv. Prot. Chem. 52, 283 (1978).

[15] Schmidt, D. G., and T. A. PAyens, Surface Colloid Sci. 9, 165 (1976).

[16] Sumner, A. K., M. A. Nielsen and C. G. Youngs, J. Food Sci. 44, 364 (1981).

[17] TORnBerg, E., J. Colloid interface Sci. 64, 391 (1978).

[18] Tornberg, E., Y. Granfeldt and C. Hakansson, J. Sci. Food Agric. 33, 904 (1982).

[19] Vose, J. R., Cereal Chem. 57, 406 (1980).

[20] Ward, A. F. H., and L. Tordai, J. Chem. Physics. 14, 453 (1946).

Dr. J. Gueguen, Ministere de l'Agriculture, Institut National de la Recherche Agronomique, Laboratoire de Biochimie et Technologie des Protéines, Centre Agro Alimentaire, Rue de la Géraudière, 44072 NantesCédex, France 
Die Nahrung 30 (1986) 3-4, 348

\title{
Rezensionen
}

\author{
В. А. Солоухин, Л. В. ГАРиБовА, А. Д. ТуровА и др.: Дары природы
}

(V. A. Solouchin, L. V. Garibova, A. D. Turova u. a.: Geschenke der Natur) 304 Seiten, 175 Abb. Verlag Ekonomika, Moskau 1984. Preis: 5,10 Rbl.; 25,50 M.

Das sehr schön und reichhaltig illustrierte, von Schriftstellern und Wissenschaftlern verschiedener naturwissenschaftlicher Fachrichtungen zusammengestellte Buch, dessen einzelne Beiträge neben sachlichen Inhalten die Liebe der Autoren zur Natur wiedergeben, liest sich wie ein aufregender Roman. Das Buch besteht aus 3 Teilen: Kräuter, Beeren und Pilze. In den einzelnen Aufsätzen wird auf Überlieferungen, Vorkommen, Eigenschaften, Verwendungsarten, Verarbeitungsmöglichkeiten und traditionelle Produkte eingegangen. Den Abschluß eines jeden Teils bilden einige Rezeptbeispiele.

G. Pose

\section{В. В. Виноградов: Гормональные механизмы метаболического действия тиамнна}

(V. V. Vinogradov: Hormonelle Mechanismen der metabolischen Wirkung des Thiamins) 197 Seiten, 57 Abb., 17 Tab. Verlag Nauka i technika, Minsk 1984. Preis: 1,70 Rbl.; 8,50 M.

Das umfangreiche experimentelle und klinische Material, das die verschiedenen Aspekte der VitaminHormon-Beziehungen betrifft, wird vom Autor in diesem Buch in Form eines Konzeptes der hormonellen Übermittlung der metabolischen Wirkung des Thiamins dargestellt, das auf der anfänglichen Wechselwirkung des Vitamins mit Inselzellen und funktionellen Elementen der Nebennierenrinde basiert. Das Buch ist in 6 Kapitel gegliedert: Regulation vitaminabhängiger Prozesse durch Thiamin (Coenzymfunktionen), Wahrscheinlichkeit der hormonellen Übermittlung von Vitaminwirkungen (keine Coenzymfunktionen), funktionelle Verbindung des Thiamins mit der Nebennierenrinde, funktionelle Verbindungen des Thiamins mit der Bauchspeicheldrüse, Rolle des Thiamins bei der Adaptation, allgemeinmetabolische und medizinische Aspekte der Vitamin-Hormon-Wechselwirkungen.

G. PosE

\section{Л. Н. ВАлЕНКЕВич : Пищеварительная система человека прн старении}

(L. N. Valenkevič: Verdauungssystem des Menschen während des Alterns) 224 Seiten, 23 Abb., 60 Tab. Verlag Nauka, Leningrad 1984. Preis: 1,80 Rbl.; 9,00 M.

Das Buch stellt eine Zusamimenfassung der Untersuchungsergebnisse über den Zustand der Verdauungsorgane des alternden Menschen dar. Es wird auf die altersbedingten morphologischen und funktionellen Besonderheiten von Mundhöhle, Speiseröhre, Magen, Leber, Gallenblase, Gallengängen, Pankreas und Darm eingegangen. Abbau und Resorption der verschicdenen Grundnährstoffe, Mineralstoffe und Vitamine im Alter werden eingehend behandelt. Auf die Besonderheiten der Erkrankungen der Verdauungsorgane im Alter wird im einzelnen eingegangen. Es wird gezeigt, daß ungünstige Einflüsse infolge von Störungen in der Ernährung und Verdauung den Prozess des Alterns verstärken oder ins Pathologische wenden können. Große Aufmerksamkeit wird der Ernährung im Alter sowie der Behandlung gastroenterologischer Erkrankungen gerontologischer Patienten gewidmet.

G. Pose

W. Arneth, E. Hauser, G. Hilse, H. Linke, S. NeuHÄuSER und H.-J. Sinell: BBV Fleischwarenhandbuch 1. 204 Seiten, zahlreiche Tab. und Abb. B. Behr's Verlag, Hamburg 1984. Preis: 59,- DM.

Das broschiert vorliegende Handbuch wendet sich vor allem an Praktiker bzw. Führungskräfte der Fleischwarenindustrie. Von namhaften Fachleuten wird in prägnanter Weise ein Einblick in Entwicklungen im Bereich des Marktes, der Rechtsvorschriften, der Hygiene, der Ernährung, der Untersuchungstechniken sowie der Technik und Technologie der Fleischverarbeitung gegeben. Mit Hilfe zahlreicher Tabellen, Schemata und Abbildungen gelingt eine klare und übersichtliche Darstellung der verschiedenen Gebiete. Da viele Probleme nur angerissen werden können, weisen jedem Kapitel nachgestellte Literaturverzeichnisse den Wegzur vertiefenden Information. Druckfehler (z. B. S. 21, 34, 132, 173) sollten bei der nächsten Auflage getilgt werden.

H. Peters 